\title{
High-quality permanent draft genome sequence of Ensifer sp. PC2, isolated from a nitrogen-fixing root nodule of the legume tree (Khejri) native to the Thar Desert of India
}

\author{
Hukam Singh Gehlot ${ }^{1}$, Julie Ardley², Nisha Tak ${ }^{2}$ Rui Tian², Neetu Poonar ${ }^{1}$, Raju R. Meghwal', Sonam Rathi ${ }^{1}$, Ravi Tiwari ${ }^{2}$ \\ Wan Adnawani ${ }^{2}$, Rekha Seshadri ${ }^{3}$, T. B. K. Reddy ${ }^{3}$, Amrita Pati ${ }^{3}$, Tanja Woyke ${ }^{3}$, Manoj Pillay ${ }^{4}$, Victor Markowitz ${ }^{4}$, \\ Mohammed N. Baeshen ${ }^{5}$, Ahmed M. Al-Hejin ${ }^{5}$, Natalia Ivanova ${ }^{3}$, Nikos Kyrpides ${ }^{3,5}$ and Wayne Reeve ${ }^{2 *}$
}

\begin{abstract}
Ensifer sp. PC2 is an aerobic, motile, Gram-negative, non-spore-forming rod that was isolated from a nitrogen-fixing nodule of the tree legume P. cineraria (L.) Druce (Khejri), which is a keystone species that grows in arid and semi-arid regions of the Indian Thar desert. Strain PC2 exists as a dominant saprophyte in alkaline soils of Western Rajasthan. It is fast growing, well-adapted to arid conditions and is able to form an effective symbiosis with several annual crop legumes as well as species of mimosoid trees and shrubs. Here we describe the features of Ensifer sp. PC2, together with genome sequence information and its annotation. The 8,458,965 bp high-quality permanent draft genome is arranged into 171 scaffolds of 171 contigs containing 8,344 protein-coding genes and 139 RNA-only encoding genes, and is one of the rhizobial genomes sequenced as part of the DOE Joint Genome Institute 2010 Genomic Encyclopedia for Bacteria and Archaea-Root Nodule Bacteria (GEBA-RNB) project proposal.
\end{abstract}

Keywords: Root-nodule bacteria, Nitrogen fixation, Symbiosis, Ensifer, Prosopis

\section{Introduction}

The genus Prosopis (family Leguminosae, sub-family Mimosoideae [1]) comprises about 44 species that are widely distributed in the world's semi-arid regions, mostly in North and South America with a few species found in Africa and south west Asia [2-4]. Several species have been widely introduced throughout the world over the last 200 years [5]. Prosopis may have evolved from P. africana (Guill. \& Perr.) Taub., in which various character traits and small genome size (392-490 Mbp) indicate that it is a primitive species [2]. According to Burkart [2], Prosopis is an old genus that diverged early into several principal lineages, with some of these

\footnotetext{
* Correspondence: W.Reeve@murdoch.edu.au

${ }^{2}$ Centre for Studies, Murdoch University, Murdoch, Western Australia,

Australia

Full list of author information is available at the end of the article
}

lineages producing more recent episodes of speciation. This is supported by a recent molecular dating analysis that places the divergence of the New World Prosopis Sections during the Oligocene (33.9 to 23.03 Mya) [6], which is remarkably ancient considering that the subfamily Mimosoideae originated between 42-50 Mya [7]. Section Prosopis consists of three species, Prosopis cineraria (L.) Druce, P. farcta (Banks et Sol.) Eig. and P. koelziana Burkart, which are native to North Africa and Asia [6].

P. cineraria is endemic to arid and semi-arid regions of the Indian Thar Desert and is designated as the state tree of Rajasthan [8]. It symbolizes the sacred mythological "Kalpa Vriksh" (wish tree) of the desert and is historically important, as it has been worshiped since ancient times by many rural communities in these arid regions. P. cineraria is a multipurpose tree used as food, 
fodder, shelter and medicine by the local inhabitants. It is an important component of agro forestry, agrisilvicultural and silvopastoral systems in the alkaline soil of the Thar Desert. The tree is extremely drought and salt tolerant, having a deep root system (>100 metres) that helps in acquiring nutrients and moisture from deeper soil layers. It produces green pods that are rich in nutrients and antioxidants and eaten as a vegetable in the hot summer [9]. P. cineraria is a good candidate for rehabilitation of dry, marginal or degraded lands of low fertility and/or high salinity. It plays a vital role as a soil binder in the stabilization of sand dunes and enriches poor desert soil by fixing atmospheric nitrogen in association with its rhizobial microsymbionts [10-13].

Prosopis is a promiscuous genus, being nodulated by a wide range of taxonomically diverse rhizobia. Mesquite (Torr.) in the Sonoran Desert, California is nodulated by diverse strains of fast- and slow-growing rhizobia [14]. Mesorhizobium chacoense CECT $5336^{\mathrm{T}}$ is a microsymbiont of Prosopis alba Griseb. growing in the Chaco Arido region in Argentina [15], whereas in Spain is nodulated by strains of Ensifer medicae, E. meliloti and Rhizobium giardinii [16]. In Africa, the introduced Prosopis species $P$. chilensis (Molina) Stuntz, P. cineraria, P. juliflora (Sw.) DC. and P. pallida (Willd.) Kunth are reported to nodulate with strains of Ensifer arboris, E. kostiense, E. saheli and E. terangae $[17,18]$ and P. juliflora also forms effective symbioses with strains of Mesorhizobium plurifarium [19] and Rhizobium etli [20]. Nodulation of $P$. cineraria growing in its native range was first described by Basak and Goyal [10]. Recently, P. cineraria and other native legumes growing in the alkaline soils of the Thar desert have been reported to nodulate with a dominant novel group of Ensifer strains (PC2, TW10, TP13, RA9, TV3 and TF7) that are closely related to African and Australian Ensifer strains on the basis of
16S rRNA sequence similarity, but form a distinct, wellseparated cluster $[21,22]$.

The indigenous rhizobia of wild tree legumes growing in such arid and harsh environments have superior tolerance to abiotic factors such as salt stress, elevated temperatures and drought and can be used as inoculants for wild as well as crop legumes cultivated in reclaimed desert lands [10]. Because of its ability to nodulate the keystone species $P$. cineraria as well as crop legumes such as Vigna radiata (L.) R.Wilczek and V. unguiculata (L.) Walp. [21], strain PC2 has therefore been selected as part of the DOE Joint Genome Institute 2010 Genomic Encyclopedia for Bacteria and Archaea-Root Nodule Bacteria (GEBA-RNB) sequencing project [23]. Here we present a summary classification and a set of general features for Ensifer sp. strain PC2, together with a description of its genome sequence and annotation.

\section{Organism information \\ Classification and features}

Ensifer sp. PC2 is a motile, Gram-negative strain in the order Rhizobiales of the class Alphaproteobacteria. The rod shaped form (Fig. 1 Left and Center) has dimensions of approximately $0.3-0.5 \mu \mathrm{m}$ in width and $1.25-1.5 \mu \mathrm{m}$ in length. It is fast growing, forming colonies within 3-4 days when grown on half strength Lupin Agar [24], tryptone-yeast extract agar (TY) [25] or a modified yeast-mannitol agar (YMA) [26] at $28{ }^{\circ} \mathrm{C}$. Colonies on $1 / 2$ LA are white, opaque, slightly domed and slightly mucoid with smooth margins (Fig. 1 Right).

Figure 2 shows the phylogenetic relationship of Ensifer sp. PC2 in a $16 \mathrm{~S}$ rRNA sequence based tree. This strain is the most similar to Ensifer saheli LMG $7837^{\mathrm{T}}$ based on the 16S rRNA gene alignment, with sequence identities of $99.41 \%$ over $1,366 \mathrm{bp}$, as determined using the

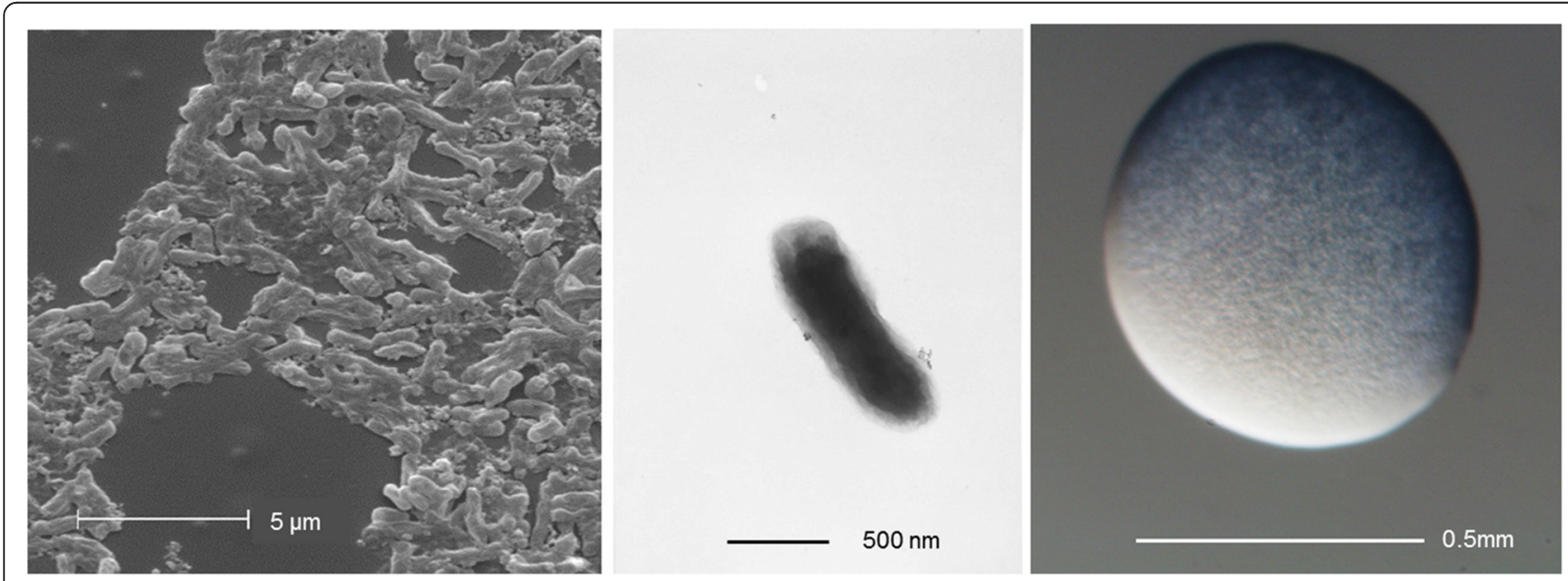

Fig. 1 Images of Ensifer sp. PC2 using scanning (Left) and transmission (Center) electron microscopy and the appearance of colony morphology on solid media (Right) 


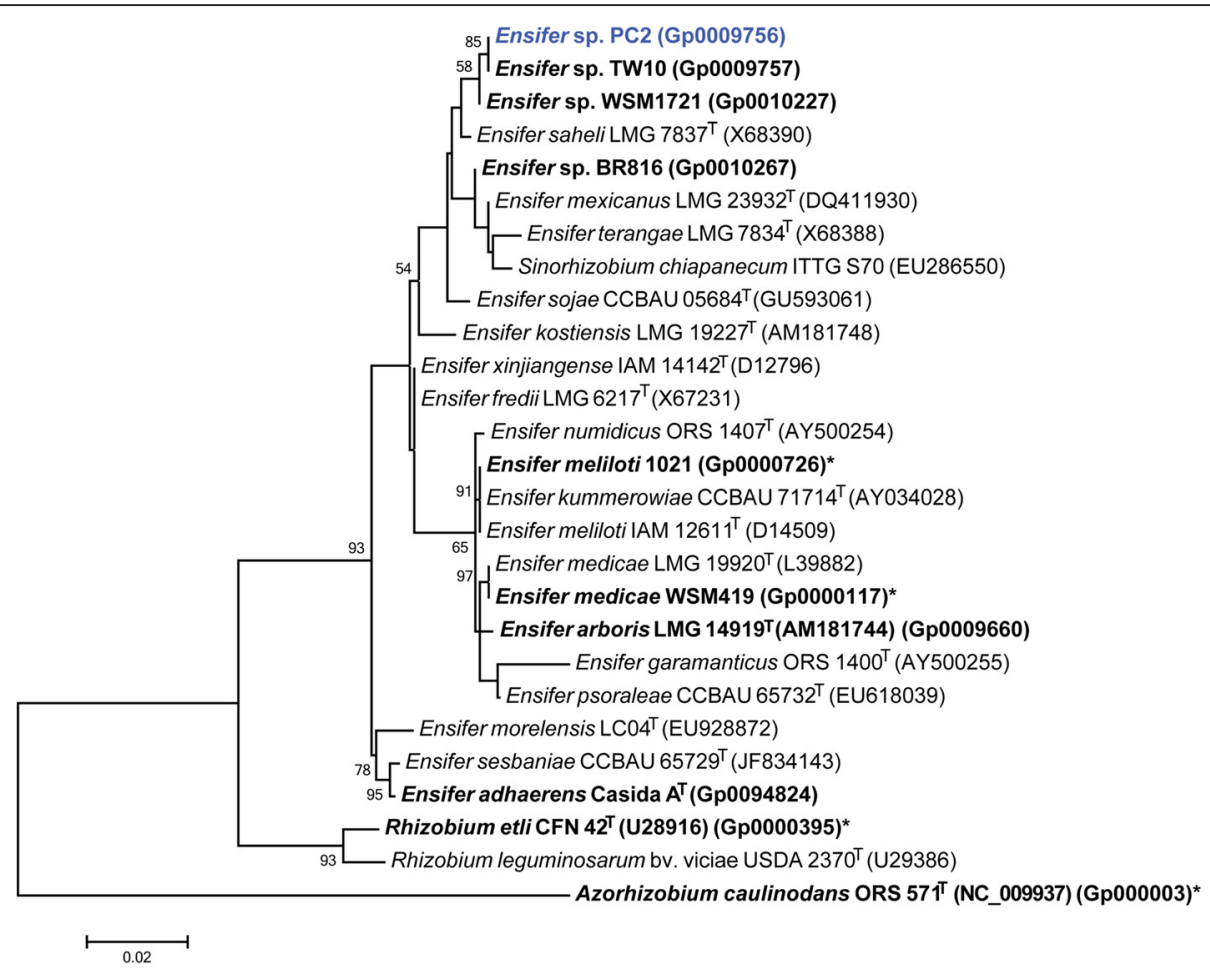

Fig. 2 Phylogenetic tree showing the relationship of Ensifer sp. PC2 (shown in bold blue print) to Ensifer spp. and other root nodule bacteria species in the order Rhizobiales, based on aligned sequences of the 16S rRNA gene (1,283 bp internal region). (The species name "Sinorhizobium chiapanecum" has not been validly published.) Azorhizobium caulinodans ORS $571^{\top}$ was used as an outgroup. All sites were informative and there were no gap-containing sites. Phylogenetic analyses were performed using MEGA, version 6 [44]. The tree was built using the MaximumLikelihood method with the General Time Reversible model [45]. Bootstrap analysis [46] with 500 replicates was performed to assess the support of the clusters. Type strains are indicated with a superscript T. Strains with a genome sequencing project registered in GOLD [29] are in bold font and the GOLD ID is provided after the GenBank accession number, where this is available. Finished genomes are indicated with an asterisk.

EzTaxon-e database, which contains the sequences of validly published type strains [27]. The PC2 $16 \mathrm{~S}$ rRNA gene sequence has $100 \%$ sequence identity with that of another Indian Thar Desert rhizobial strain, Ensifer sp. TW10, isolated from a nodule of the perennial legume Tephrosia wallichii [22]. Minimum Information about the Genome Sequence for PC2 is provided in Table 1 and Additional file 1: Table S1.

\section{Symbiotaxonomy}

Ensifer sp. strain PC2 is able to nodulate and fix nitrogen with both mimosoid and papilionoid legume hosts. It is interesting to note that sp. PC2 is able to nodulate and fix nitrogen with Acacia saligna (Labill.) Wendl., a promiscuous legume tree that mainly nodulates with species of in its native southwestern Australia range [28]. PC2 also effectively nodulates the Central American mimosoid tree Leucaena leucocephala (Lam.) de Wit. PC2 appears to be a relatively promiscuous strain that has potential to be used as an inoculant for crop legumes species such as Vigna radiata (L.) Wilczek and V. unguiculata (L.) Walp.. The symbiotic characteristics of sp. strain $\mathrm{PC} 2$ on a range of selected hosts are summarised in Additional file 2: Table S2.

\section{Genome sequencing information Genome project history}

This organism was selected for sequencing on the basis of its environmental and agricultural relevance to issues in global carbon cycling, alternative energy production, and biogeochemical importance, and is part of the Genomic Encyclopedia of Bacteria and Archaea, The Root Nodulating Bacteria chapter project at the U.S. Department of Energy, Joint Genome Institute. The genome project is deposited in the Genomes OnLine Database [29] and a high-quality permanent draft genome sequence is deposited in IMG [30]. Sequencing, finishing and annotation were performed by the JGI [31]. A summary of the project information is shown in Table 2.

\section{Growth conditions and genomic DNA preparation}

Ensifer sp. PC2 was streaked onto TY solid medium [25, 32] and grown at $28{ }^{\circ} \mathrm{C}$ for three days to obtain well grown, well separated colonies, then a single colony was selected and used to inoculate $5 \mathrm{ml}$ TY broth medium. The culture was grown for $48 \mathrm{~h}$ on a gyratory shaker (200 rpm) at $28{ }^{\circ} \mathrm{C}$. Subsequently $1 \mathrm{ml}$ was used to inoculate $60 \mathrm{ml}$ TY broth medium and grown on a 
Table 1 Classification and general features of Ensifer sp. PC2 in accordance with the MIGS recommendations [47] published by the Genome Standards Consortium [48]

\begin{tabular}{|c|c|c|c|}
\hline MIGS ID & Property & Term & Evidence code ${ }^{a}$ \\
\hline & Current classification & Domain Bacteria & TAS [49] \\
\hline & & Phylum Proteobacteria & TAS $[50,51]$ \\
\hline & & Class Alphaproteobacteria & TAS $[52,53]$ \\
\hline & & Order Rhizobiales & TAS [54] \\
\hline & & Family Rhizobiaceae & TAS [55] \\
\hline & & Genus Ensifer & TAS [56-58] \\
\hline & & Species Ensifer sp. & IDA \\
\hline & & Strain: PC2 & TAS [21] \\
\hline & Gram stain & Negative & IDA \\
\hline & Cell shape & Rod & IDA \\
\hline & Motility & Motile & IDA \\
\hline & Sporulation & Non-sporulating & NAS \\
\hline & Temperature range & $10-40^{\circ} \mathrm{C}$ & IDA \\
\hline & Optimum temperature & $28^{\circ} \mathrm{C}$ & IDA \\
\hline & pH range; Optimum & $5-9.5 ; 6.5-8$ & IDA \\
\hline & Carbon source & Mannitol, tryptone, yeast extract & TAS [21] \\
\hline MIGS-6 & Habitat & Soil; root nodule on host (Prosopis (L.) Druce) & TAS [21] \\
\hline MIGS-6.3 & Salinity & $0.89-2.0 \%(w / v)$ & NAS \\
\hline MIGS-22 & Oxygen requirement & Aerobic & TAS [21] \\
\hline MIGS-15 & Biotic relationship & Free living, symbiotic & TAS [21] \\
\hline MIGS-14 & Pathogenicity & Biosafety level 1 & TAS [59] \\
\hline MIGS-4 & Geographic location & Jodhpur, Indian Thar Desert & TAS [21] \\
\hline MIGS-5 & Sample collection & October, 2009 & TAS [21] \\
\hline MIGS-4.1 & Latitude & 26.27061 & TAS [21] \\
\hline MIGS-4.2 & Longitude & 73.021177 & TAS [21] \\
\hline MIGS-4.3 & Depth & $0-10 \mathrm{~cm}$ & NAS \\
\hline MIGS-4.4 & Altitude & $234 m$ & TAS [21] \\
\hline
\end{tabular}

a Evidence codes - IDA: Inferred from Direct Assay; TAS: Traceable Author Statement (i.e., a direct report exists in the literature); NAS: Non-traceable Author Statement (i.e., not directly observed for the living, isolated sample, but based on a generally accepted property for the species, or anecdotal evidence). These evidence codes are from the Gene Ontology project [60], [http://geneontology.org/page/guide-go-evidence-codes]

gyratory shaker $(200 \mathrm{rpm})$ at $28^{\circ} \mathrm{C}$ until $\mathrm{OD}_{600 \mathrm{~nm}} 0.6$ was reached. DNA was isolated from $60 \mathrm{ml}$ of cells using a CTAB bacterial genomic DNA isolation method [http:// jgi.doe.gov/collaborate-with-jgi/pmo-overview/protocolssample-preparation-information/]. Final concentration of the DNA was $0.5 \mathrm{mg} \mathrm{ml}^{-1}$.

\section{Genome sequencing and assembly}

The draft genome of sp. PC2 was generated at the JGI using the Pacific Biosciences (PacBio) technology. A PacBio SMRTbell ${ }^{\text {TM }}$ library was constructed and sequenced on the PacBio RS platform, which generated 403,200 filtered subreads totaling $1.1 \mathrm{Gbp}$. All general aspects of library construction and sequencing performed at the JGI can be found on the JGI website [http://jgi.doe.gov/].
The raw reads were assembled using HGAP (version: 2.0.12.0.1) [33]. The final draft assembly contained 171 contigs in 171 scaffolds, totalling $8.5 \mathrm{Mbp}$ in size. The input read coverage was $181.5 x$.

\section{Genome annotation}

Genes were identified using Prodigal [34] as part of the DOE-JGI genome annotation pipeline $[35,36]$. The predicted CDSs were translated and used to search the National Center for Biotechnology Information nonredundant database, UniProt, TIGRFam, Pfam, KEGG, COG, and InterPro databases. The tRNAScanSE tool [37] was used to find tRNA genes, whereas ribosomal RNA genes were found by searches against models of the ribosomal RNA genes built from SILVA [38]. Other non-coding RNAs such as the RNA components of the protein secretion complex 
Table 2 Genome sequencing project information for Ensifer sp.

\begin{tabular}{|c|c|c|}
\hline $\begin{array}{l}\text { MIGS } \\
\text { ID }\end{array}$ & Property & Term \\
\hline $\begin{array}{l}\text { MIGS- } \\
31\end{array}$ & Finishing quality & High-quality draft \\
\hline $\begin{array}{l}\text { MIGS- } \\
28\end{array}$ & Libraries used & Pacbio SMRTbell ${ }^{\mathrm{TM}}$ library \\
\hline $\begin{array}{l}\text { MIGS- } \\
29\end{array}$ & $\begin{array}{l}\text { Sequencing } \\
\text { platforms }\end{array}$ & Pacific Biosciences RS \\
\hline $\begin{array}{l}\text { MIGS- } \\
31.2\end{array}$ & Fold coverage & $181.5 x$ \\
\hline $\begin{array}{l}\text { MIGS- } \\
30\end{array}$ & Assemblers & HGAP (version: 2.0.12.0.1) \\
\hline \multirow[t]{6}{*}{$\begin{array}{l}\text { MIGS- } \\
32\end{array}$} & $\begin{array}{l}\text { Gene calling } \\
\text { methods }\end{array}$ & Prodigal 1.4 \\
\hline & Locus Tag & $\begin{array}{l}\text { B077 [http://www.ncbi.nlm.nih.gov/ } \\
\text { bioproject/?term=B077] }\end{array}$ \\
\hline & GenBank ID & LATE00000000 \\
\hline & $\begin{array}{l}\text { GenBank Date of } \\
\text { Release }\end{array}$ & Apr 202015 \\
\hline & GOLD ID & $\begin{array}{l}\text { Gp0009756 [https://gold.jgi-psf.org/ } \\
\text { project?id=9756] }\end{array}$ \\
\hline & BIOPROJECT ID & PRNJA169749 \\
\hline \multirow[t]{2}{*}{$\begin{array}{l}\text { MIGS- } \\
13\end{array}$} & $\begin{array}{l}\text { Source Material } \\
\text { Identifier }\end{array}$ & PC2, WSM4384 \\
\hline & Project relevance & Symbiotic $\mathrm{N}_{2}$ fixation, agriculture \\
\hline
\end{tabular}

Table 3 Genome statistics for Ensifer sp. PC2

\begin{tabular}{lll}
\hline Attribute & Value & \% of Total \\
\hline Genome size (bp) & $8,458,965$ & 100.00 \\
DNA coding (bp) & $7,124,539$ & 84.22 \\
DNA G + C (bp) & $5,187,131$ & 61.32 \\
DNA scaffolds & 171 & 100.00 \\
Total genes & 8483 & 100.00 \\
Protein coding genes & 8344 & 98.36 \\
RNA genes & 139 & 1.64 \\
Pseudo genes & 0 & - \\
Genes in internal clusters & 513 & 6.05 \\
Genes with function prediction & 6290 & 74.15 \\
Genes assigned to COGs & 5205 & 61.36 \\
Genes assigned Pfam domains & 6533 & 77.01 \\
Genes with signal peptides & 645 & 7.60 \\
Genes with transmembrane helices & 1733 & 20.43 \\
CRISPR repeats & 1 & - \\
\hline
\end{tabular}

and the RNase $\mathrm{P}$ were identified by searching the genome for the corresponding Rfam profiles using INFERNAL [39]. Additional gene prediction analysis and manual functional annotation was performed within the Integrated Microbial Genomes platform [40] developed by the Joint Genome Institute, Walnut Creek, CA, USA [41].

\section{Genome properties}

The genome is 8,458,965 nucleotides with $61.32 \%$ GC content (Table 3) and comprised of 171 scaffolds of 171 contigs. From a total of 8,483 genes, 8,344 were protein encoding and 139 RNA only encoding genes. The majority of protein-coding genes $(76.34 \%)$ were assigned a putative function whilst the remaining genes were annotated as

Table 4 Number of genes of sp. PC2 associated with general COG functional categories

\begin{tabular}{|c|c|c|c|}
\hline Code & Value & $\begin{array}{l}\text { \%age of total } \\
(5,205)\end{array}$ & Description \\
\hline J & 236 & 4.01 & $\begin{array}{l}\text { Translation, ribosomal structure and } \\
\text { biogenesis }\end{array}$ \\
\hline A & 0 & 0.00 & RNA processing and modification \\
\hline K & 514 & 8.74 & Transcription \\
\hline L & 172 & 2.92 & Replication, recombination and repair \\
\hline B & 2 & 0.03 & Chromatin structure and dynamics \\
\hline D & 47 & 0.80 & $\begin{array}{l}\text { Cell cycle control, cell division, } \\
\text { chromosome partitioning }\end{array}$ \\
\hline Y & 0 & 0.00 & Nuclear structure \\
\hline V & 115 & 1.95 & Defense mechanisms \\
\hline $\mathrm{T}$ & 271 & 4.61 & Signal transduction mechanisms \\
\hline M & 331 & 5.63 & Cell wall/membrane/envelope biogenesis \\
\hline N & 101 & 1.72 & Cell motility \\
\hline Z & 0 & 0.00 & Cytoskeleton \\
\hline W & 44 & 0.75 & Extracellular structures \\
\hline U & 132 & 2.24 & $\begin{array}{l}\text { Intracellular trafficking, secretion, and } \\
\text { vesicular transport }\end{array}$ \\
\hline O & 213 & 3.62 & $\begin{array}{l}\text { Posttranslational modification, protein } \\
\text { turnover, chaperones }\end{array}$ \\
\hline C & 351 & 5.97 & Energy production and conversion \\
\hline G & 548 & 9.31 & Carbohydrate transport and metabolism \\
\hline E & 598 & 10.16 & Amino acid transport and metabolism \\
\hline $\mathrm{F}$ & 116 & 1.97 & Nucleotide transport and metabolism \\
\hline $\mathrm{H}$ & 277 & 4.71 & Coenzyme transport and metabolism \\
\hline । & 227 & 3.86 & Lipid transport and metabolism \\
\hline$P$ & 309 & 5.25 & Inorganic ion transport and metabolism \\
\hline Q & 171 & 2.91 & $\begin{array}{l}\text { Secondary metabolite biosynthesis, } \\
\text { transport and catabolism }\end{array}$ \\
\hline $\mathrm{R}$ & 593 & 10.08 & General function prediction only \\
\hline$S$ & 395 & 6.71 & Function unknown \\
\hline$x$ & 120 & 2.04 & Mobilome: prophages, transposons \\
\hline - & 3,278 & 38.64 & Not in COGS \\
\hline
\end{tabular}


hypothetical. The distribution of genes into COGs functional categories is presented in Table 4.

\section{Insights from the genome sequence}

With a genome totaling $8.5 \mathrm{Mbp}$ in size, Ensifer sp. PC2 is approximately $25 \%$ larger than the average Ensifer genome in GenBank. Although PC2 shares $100 \% 16 \mathrm{~S}$ rRNA sequence identity and 99.17 Average Nucleotide Identity with Ensifer sp. TW10, also isolated from a Thar Desert woody legume, the genome of TW10 has a smaller size of $6.8 \mathrm{Mbp}$. PC2 contains over 1,000 genes that are not found in TW10, including two plasmid replication initiator proteins and a suite of genes ( $v i r / t r b)$ involved in conjugative transfer. From this it is assumed that the PC2 genome is multipartite and contains at least one conjugative plasmid. In PC2, 38.64 \% of genes have not been assigned to a COG functional category, whereas in TW10, only $31.55 \%$ have not been assigned to a COG functional category. Compared with TW10, PC2 has a much higher number of genes assigned to the mobilome category (54 and 120 genes, respectively) and to extracellular structures ( 29 and 44 genes, respectively).

\section{Conclusion}

Based on the 16S rRNA gene alignment, Ensifer sp. PC2 is most closely related to Ensifer sp. TW10 and Ensifer sp. WSM1721, two strains isolated from perennial legumes growing in arid climates and alkaline soils in India and Australia, respectively [21, 42]. Ensifer fredii strains isolated from Chinese soybean were also superdominant in sampling sites with alkaline-saline soils [43], which suggests that the biogeographic distribution of several Ensifer spp. is linked to their adaptation to alkaline soils. Further, this suggests that the symbiotic associations formed by promiscuous legumes, such as Prosopis, are likely to vary depending on which rhizobial genera are best adapted to the edaphic conditions in which the host is growing.

The ability of PC2 to fix nitrogen with both $P$. cineraria (L.) Druce and the crop legumes Vigna radiata (L.) R.Wilczek and V. unguiculata (L.) Walp. makes it a valuable inoculant strain for use in arid, alkaline regions such as the Thar desert. Analysis of the PC2 sequenced genome and comparison with the genomes of sequenced Ensifer spp. and other rhizobia will provide insights into the molecular basis of the patterns seen in rhizobial biogeographic distributions and associations with plant hosts and into the molecular determinants of rhizobial tolerance to arid and alkaline environments.

\section{Additional files}

Additional file 1: Table S1. Associated MIGS record for PC2 (DOCX $19 \mathrm{~kb}$ )

Additional file 2: Table S2. Nodulation and $\mathrm{N}_{2}$ fixation properties of Ensifer sp. PC2 on selected legume hosts. (DOCX $17 \mathrm{~kb}$ )

\section{Abbreviations}

ANI: Average nucleotide identity; GEBA-RNB: Genomic encyclopedia for bacteria and archaea-root nodule bacteria; IMG: Integrated microbial genomes.

\section{Acknowledgements}

This work was performed under the auspices of the US Department of Energy's Office of Science, Biological and Environmental Research Program, and by the University of California, Lawrence Berkeley National Laboratory under contract No. DE-AC02-05CH11231. We thank Gordon Thomson (Murdoch University) for the preparation of SEM and TEM photos. We would also like to thank the Center of Nanotechnology at King Abdulaziz University for their support and acknowledge King Abdulaziz University Vice President for Educational Affairs Prof. Abdulrahman O. Alyoubi for his support. We sincerely acknowledge funding received from University Grant Commission, New Delhi, India for UGC-SAPII-CAS-I, UGC-BSR Research StartUp- Grant (F.30-16/2014-BSR); Department of Biotechnology, Govt. of India (BT/PR11461/ AGR/21/270/2008). We also thank the Crawford Fund AwardATSE, Australia for funding $H G$ and NT to conduct research at the CRS.

\section{Authors' contribution}

HG supplied the strain, DNA and background information for this project, TR supplied DNA to JGl and performed all imaging, JA and NT drafted the paper, MNB and AMA-H provided financial support and all other authors were involved in sequencing the genome and/or editing the final paper. All authors read and approved the final manuscript.

\section{Competing interests}

The authors declare that they have no competing interests.

\section{Author details}

${ }^{1}$ BNF and Stress Biology Lab., Department of Botany, J.N. Vyas University, Jodhpur 342001, India. '2Centre for Studies, Murdoch University, Murdoch, Western Australia, Australia. ${ }^{3}$ DOE Joint Genome Institute, Walnut Creek, California, USA. ${ }^{4}$ Biological Data Management and Technology Center, Lawrence Berkeley National Laboratory, Berkeley, California, USA.

${ }^{5}$ Department of Biological Sciences, Faculty of Science, King Abdulaziz University, Jeddah, Saudi Arabia.

Received: 4 September 2015 Accepted: 18 May 2016

Published online: 23 June 2016

\section{References}

1. Lewis G, Schrire B, Mackinder B, Lock M. Legumes of the World. Richmond, Surrey: Royal Botanic Gardens, Kew; 2005.

2. Burkart A. A monograph of the genus Prosopis (Leguminosae Subfam, Mimosoideae). J Arnold Arbor. 1976;57:219-49. 450-525.

3. Felker P. Unusual physiological properties of the arid adapted tree legume Prosopis and their applications in developing countries. In: De la Barrera E, Smith WK, editors. Perspectives in Biophysical Plant Ecophysiology: A Tribute to Park S Nobel. Mexico City: Universidad Nacional Autónoma de México: 2009. p. 221-55

4. Sprent JI. Nodulation in Legumes. Richmond, Surrey: Royal Botanic Gardens, Kew; 2001

5. Pasiecznik NM, Harris PJC, Smith SJ: Identifying tropical Prosopis species: a field guide. Coventry: Henry Doubleday Research Association; 2003

6. Catalano SA, Vilardi JC, Tosto D, Saidman BO. Molecular phylogeny and diversification history of Prosopis (Fabaceae: Mimosoideae). Biol J Linnean Soc. 2008;93:621-40

7. Lavin M, Herendeen PS, Wojciechowski MF. Evolutionary rates analysis of Leguminosae implicates a rapid diversification of lineages during the Tertiary. Syst Biol. 2005:54:575-94.

8. Bhandari MM. Flora of the Indian Desert. Jodhpur: MPS Repros; 1990. 
9. Rani B, Singh U, Sharma R, Gupta A, Dhawan NG, Sharama AK, Sharma S, Maheshwari RK. Prosopis cineraria (L.) Druce: A desert tree to brace livelihood in Rajasthan. Asian J Pharmaceut Res Health Care. 2013;5:58-64.

10. Basak MK, Goyal SK. Studies on tree legumes: nodulation pattern and characterization of the symbiont. Ann Arid Zone. 1975;14:367-70.

11. Felker P: Mesquite: an all-purpose leguminous arid land tree. In New Agricultural Crops. Edited by Ritchie GA. Golden, Colorado: American Association for the Advancement of Science, Westview Press; 1979: 89-132

12. Hocking D. Trees for Drylands. Madison, Wisconsin: International Science Publisher; 1993.

13. Tewari JC, Pasiecznik NM, Harsh LN, Harris PJC: Prosopis species in the arid and semi-arid zones of India. In Proceedings of the Prosopis Conference; Central Arid Zone Research Institute, Jodhpur, Rajasthan, India. The Prosopis Society of India and the Henry Doubleday Research Association; 1993: 128 pp.

14. Thomas PM, Golly KF, Zyskind JW, Virginia RA. Variation of clonal, mesquiteassociated rhizobial and bradyrhizobial populations from surface and deep soils by symbiotic gene region restriction fragment length polymorphism and plasmid profile analysis. Appl Environ Microb. 1994;60:1146-53.

15. Velázquez E, Igual JM, Willems A, Fernández MP, Muñoz E, Mateos PF, Abril A Toro N, Normand P, Cervantes E, Gillis M, Martínez-Molina E. Mesorhizobium chacoense sp. nov., a novel species that nodulates Prosopis alba in the Chaco Arido region (Argentina). Int J Syst Evol Microbiol. 2001;51:1011-21.

16. Iglesias O, Rivas R, García-Fraile P, Abril A, Mateos PF, Martinez-Molina E, Velázquez E. Genetic characterization of fast-growing rhizobia able to nodulate Prosopis alba in North Spain. FEMS Microbiol Lett. 2007;277:210-6.

17. Räsänen L, Sprent J, Lindström K Symbiotic properties of sinorhizobia isolated from Acacia and Prosopis nodules in Sudan and Senegal. Plant Soil. 2001;235:193-210.

18. Nick G, de Lajudie P, Eardly BD, Suomalainen S, Paulin L, Zhang X, Gillis M, Lindström K. Sinorhizobium arboris sp. nov. and Sinorhizobium kostiense sp. nov., isolated from leguminous trees in Sudan and Kenya. Int J Syst Bacteriol. 1999;49: 1359-68.

19. de Lajudie P, Willems A, Nick G, Moreira F, Molouba F, Hoste B, Torck U, Neyra M, Collins MD, Lindström K, Dreyfus B, Gillis M. Characterization of tropical tree rhizobia and description of Mesorhizobium plurifarium sp. nov. Int J Syst Bacteriol. 1998;48:369-82.

20. Odee DW, Haukka K, McInroy SG, Sprent JI, Sutherland JM, Young JPW. Genetic and symbiotic characterization of rhizobia isolated from tree and herbaceous legumes grown in soils from ecologically diverse sites in Kenya. Soil Biol Biochem. 2002;34:801-11.

21. Gehlot HS, Panwar D, Tak N, Tak A, Sankhla IS, Poonar N, Parihar R, Shekhawat NS, Kumar M, Tiwari R, Ardley J, James EK, Sprent JI. Nodulation of legumes from the Thar desert of India and molecular characterization of their rhizobia. Plant Soil. 2012;357:227-43.

22. Tak N, Gehlot HS, Kaushik M, Choudhary S, Tiwari R, Tian R, Hill YJ, Bräu L, Goodwin L, Han J, Liolios K, Huntemann M, Palaniappan K, Pati A, Mavromatis K, Ivanova NN, Markowitz VM, Woyke T, Kyrpides NC, Reeve WG. Genome sequence of Ensifer sp. TW10; a Tephrosia wallichii (Biyani) microsymbiont native to the Indian Thar Desert. Stand Genomic Sci. 2013;9:304-14.

23. Reeve WG, Ardley JK, Tian R, Eshragi L, Yoon JW, Ngamwisetkun P, Seshadri R, Ivanova NN, Kyrpides NC. A genomic encyclopedia of the root nodule bacteria: Assessing genetic diversity through a systematic biogeographic survey. Stand Genomic Sci. 2014;10:14.

24. Howieson JG, Ewing MA, D'antuono MF. Selection for acid tolerance in Rhizobium meliloti. Plant Soil. 1988;105:179-88.

25. Beringer JE. R factor transfer in Rhizobium leguminosarum. J Gen Microbiol. 1974;84:188-98.

26. Vincent JM. A manual for the practical study of the root-nodule bacteria. International Biological Programme. Oxford, UK: Blackwell Scientific Publications; 1970

27. Kim O-S, Cho Y-J, Lee K, Yoon S-H, Kim M, Na H, Park S-C, Jeon YS, Lee J-H Yi H, Won S, Chun J. Introducing EzTaxon-e: a prokaryotic 16S rRNA gene sequence database with phylotypes that represent uncultured species. Int J Syst Evol Microbiol. 2012;62:716-21.

28. Marsudi NDS, Glenn AR, Dilworth MJ. Identification and characterization of fast- and slow-growing root nodule bacteria from South-Western Australian soils able to nodulate Acacia saligna. Soil Biol Biochem. 1999;31:1229-38.

29. Reddy TBK, Thomas AD, Stamatis D, Bertsch J, Isbandi M, Jansson J, Mallajosyula J, Pagani I, Lobos EA, Kyrpides NC. The Genomes OnLine Database (GOLD) v.5: a metadata management system based on a four level (meta)genome project classification. Nucleic Acids Res. 2014;43:D1099-106.
30. Markowitz VM, Chen I-MA, Palaniappan K, Chu K, Szeto E, Pillay M, Ratner A, Huang J, Woyke T, Huntemann M, Anderson I, Billis K, Varghese N, Mavromatis K, Pati A, Ivanova NN, Kyrpides NC. IMG 4 version of the integrated microbial genomes comparative analysis system. Nucleic Acids Res. 2014;42:D560-7.

31. Mavromatis K, Land ML, Brettin TS, Quest DJ, Copeland A, Clum A, Goodwin L, Woyke T, Lapidus A, Klenk HP, Cottingham RW, Kyrpides NC. The fast changing landscape of sequencing technologies and their impact on microbial genome assemblies and annotation. PLOS One. 2012;7:e48837.

32. Reeve WG, Tiwari RP, Worsley PS, Dilworth MJ, Glenn AR, Howieson JG. Constructs for insertional mutagenesis, transcriptional signal localization and gene regulation studies in root nodule and other bacteria. Microbiology. 1999:145:1307-16.

33. Chin C-S, Alexander DH, Marks P, Klammer AA, Drake J, Heiner C, Clum A, Copeland A, Huddleston J, Eichler EE, Turner SW, Korlach J. Nonhybrid, finished microbial genome assemblies from long-read SMRT sequencing data. Nat Meth. 2013;10:563-9.

34. Hyatt D, Chen GL, Locascio PF, Land ML, Larimer FW, Hauser LJ. Prodigal: prokaryotic gene recognition and translation initiation site identification. BMC Bioinformatics. 2010;11:119.

35. Mavromatis K, Ivanova NN, Chen IM, Szeto E, Markowitz VM, Kyrpides NC. The DOE-JGI Standard operating procedure for the annotations of microbial genomes. Stand Genomic Sci. 2009;1:63-7.

36. Chen IMA, Markowitz VM, Chu K, Anderson I, Mavromatis K, Kyrpides NC, Ivanova NN. Improving microbial genome annotations in an integrated database context. PLoS One. 2013;8:e54859.

37. Lowe TM, Eddy SR. tRNAscan-SE: a program for improved detection of transfer RNA genes in genomic sequence. Nucleic Acids Res. 1997;25:955-64.

38. Pruesse E, Quast C, Knittel K, Fuchs BM, Ludwig W, Peplies J, Glöckner FO. SILVA: a comprehensive online resource for quality checked and aligned ribosomal RNA sequence data compatible with ARB. Nucleic Acids Res. 2007;35:7188-96

39. INFERNAL. Inference of RNA alignments [http://eddylab.org/infernal/]. Accessed 24 May 2016.

40. The Integrated Microbial Genomes (IMG) platform [http://img.jgi.doe.gov]. Accessed 24 May 2016.

41. Markowitz VM, Mavromatis K, Ivanova NN, Chen IM, Chu K, Kyrpides NC. IMG ER: a system for microbial genome annotation expert review and curation. Bioinformatics. 2009;25:2271-8.

42. Yates RJ, Howieson JG, Nandasena KG, O'Hara GW. Root-nodule bacteria from indigenous legumes in the north-west of Western Australia and their interaction with exotic legumes. Soil Biol Biochem. 2004;36:1319-29.

43. Zhang YM, Li Y, Chen WF, Wang ET, Tian CF, Li QQ, Zhang YZ, Sui XH, Chen WX. Biodiversity and biogeography of rhizobia associated with soybean plants grown in the North China Plain. Appl Environ Microb. 2011;77:6331-42.

44. Tamura K, Stecher G, Peterson D, Filipski A, Kumar S. MEGA6: Molecular Evolutionary Genetics Analysis Version 6.0. Mol Biol Evol. 2013;30(12):2725-9.

45. Nei M, Kumar S. Molecular Evolution and Phylogenetics. New York: Oxford University Press; 2000.

46. Felsenstein J. Confidence limits on phylogenies: an approach using the bootstrap. Evolution. 1985;39:783-91.

47. Field D, Garrity G, Gray T, Morrison N, Selengut J, Sterk P, Tatusova T, Thomson N, Allen M, Angiuoli SV, Ashburner M, Axelrod N, Baldauf S, Ballard S, Boore JL, Cochrane G, Cole J, Dawyndt P, de Vos P, de Pamphilis C, Edwards R, Faruque N, Feldman R, Gilbert J, Gilna P, Glöckner FO, Goldstein P, Guralnick R, Haft D, Hancock D, et al. Towards a richer description of our complete collection of genomes and metagenomes "Minimum Information about a Genome Sequence " (MIGS) specification. Nature Biotechnol. 2008; 26:541-7.

48. Field D, Amaral-Zettler L, Cochrane G, Cole JR, Dawyndt P, Garrity GM, Gilbert J, Glöckner FO, Hirschman L, Karsch-Mizrachi I, Klenk H-P, Knight R, Kottmann R, Kyrpides N, Meyer F, San Gil I, Sansone S-A, Schriml LM, Sterk P, Tatusova T, Ussery DW, White O, Wooley J. The Genomic Standards Consortium. PLoS Biology. 2011;9:e1001088.

49. Woese CR, Kandler O, Wheelis ML. Towards a natural system of organisms: proposal for the domains Archaea, Bacteria, and Eucarya. Proc Natl Acad Sci U S A. 1990;87:4576-9.

50. Validation of publication of new names and new combinations previously effectively published outside the IJSEM. Int J Syst Evol Microbio/ 2005, 55: 2235-2238 
51. Garrity GM, Bell JA, Phylum LT, XIV. Proteobacteria phyl. nov. In: Garrity GM, Brenner DJ, Krieg NR, Staley JT, editors. Bergey's Manual of Systematic Bacteriology, vol. 2. 2nd ed. Springer, New York: Part B; 2005. p. 1.

52. List of new names and new combinations previously effectively, but not validly, published. International Journal of Systematic and Evolutionary Microbiology 2006, 56:1-6.

53. Garrity GM, Bell JA, Lilburn T: Class I. Alphaproteobacteria class. nov. In Bergey's Manual of Systematic Bacteriology. Second edition. Edited by Garrity GM, Brenner DJ, Kreig NR, Staley JT: New York: Springer; 2005

54. Kuykendall LD: Order VI. Rhizobiales ord. nov. In Bergey's Manual of Systematic Bacteriology. Second edition. Edited by Garrity GM, Brenner DJ, Kreig NR, Staley JT: New York: Springer; 2005: 324

55. Kuykendall LD. Family I. Rhizobizceae. In: Garrity GM, Brenner DJ, Krieg NR Staley JT, editors. Bergey's Manual of Systematic Bacteriology. New York: Springer; 2005

56. Kuykendall LD, Hashem FM, Wang ET: Genus VII. Ensifer. In Bergey's Manual of Systematic Bacteriology. Volume 2. Edited by Garrity GM, Brenner DJ, Krieg NR, Staley JT. New York: Springer; 2005: 358-361

57. Judicial Commission of the International Committee on Systematics of Prokaryotes. The genus name Sinorhizobium Chen et al. 1988 is a later synonym of Ensifer Casida 1982 and is not conserved over the latter genus name, and the species name 'Sinorhizobium adhaerens' is not validly published. Opinion 84. Int J Syst Evol Microbiol. 2008;58:1973.

58. Casida LE. Ensifer adhaerens gen. nov., sp. nov.: a bacterial predator of bacteria in soil. Int J Syst Bacteriol. 1982;32:339-45.

59. Biological Agents: Technical rules for biological agents. [http://www.baua. de/en/Topics-from-A-to-Z/BiologicalAgents/TRBA/TRBA.html]. Accessed 24 May 2016.

60. Ashburner M, Ball CA, Blake JA, Botstein D, Butler H, Cherry JM, Davis AP, Dolinski K, Dwight SS, Eppig JT, Harris MA, Hill DP, Issel-Tarver L, Kasarskis A, Lewis S, Matese JC, Richardson JE, Ringwald M, Rubin GM, Sherlock G. Gene ontology: tool for the unification of biology. The Gene Ontology Consortium Nat Genet. 2000:25:25-9.

\section{Submit your next manuscript to BioMed Central and we will help you at every step:}

- We accept pre-submission inquiries

- Our selector tool helps you to find the most relevant journal

- We provide round the clock customer support

- Convenient online submission

- Thorough peer review

- Inclusion in PubMed and all major indexing services

- Maximum visibility for your research

Submit your manuscript at www.biomedcentral.com/submit 